\title{
EVALUATION OF THE SURFACE RUNOFF ESTIMATED BY THE MEXICAN OFFICIAL STANDARD AND SCS-CN MODEL IN TWO SMALL BASINS IN MEXICO
}

\author{
JORGE VÍCTOR PRADO-HERNÁNDEZ ${ }^{1 *}$, PEDRO RIVERA-DÍAZ ${ }^{2}$, DAVID CRISTÓBAL-ACEVEDO ${ }^{1}$, \\ ANTONIO MARTÍNEZ-RUÍZ ${ }^{3}$, FERMÍN PASCUAL-RAMÍREZ ${ }^{4}$, \\ JOEL PINEDA-PINEDA ${ }^{1} \&$ ÓSCAR GERARDO VALENTÍN-PAZ ${ }^{5}$ \\ ${ }^{1}$ Soils Department, University of Chapingo, México \\ ${ }^{2}$ Subcoordination of Integrated Basin Management, Mexican Institute of Water Technologies, México \\ ${ }^{3}$ National Institute of Forestry, Agriculture and Livestock Research (INIFAP), México \\ ${ }^{4}$ Research Institute on Ecosystems and Sustainability (IIES), UNAM, Campus Morelia, México \\ ${ }^{5}$ Irrigation Department, University of Chapingo, México
}

\begin{abstract}
The determination of the surface runoff depth in the microbasins of Mexico is carried out by estimation methods whose degree of accuracy is unknown, due to the information about temporal evolution of the precipitation and direct surface runoff is scarce. For this reason, it is necessary a revision of the accuracy of the available methodologies to estimate surface runoff for ungauged basins in order to identify the most appropriate for the mexican conditions. The aim of the present work was the evaluation of the Mexican Official Standard (NOM) and the Soil Conservation Service Curve Number (SCS-CN) methodologies to estimate the surface runoff depth in the microbasins Rio Chapingo and El Malacate, which are located in the state of Mexico and Michoacan respectively, with the measured information of precipitation and direct surface runoff of two recent years. With the SCS-CN method, the CN values were extracted by two ways: (1) with the tables of National Engineering Handbook (SCS-CN-NEH); and (2) with asymptotic functions (SCS-CN-AF) that associate the $\mathrm{CN}$ with precipitation, using ordered pairs method. According to the values of the statistics measures AE (mm), RE, RMSE (mm) and Nash-Sutcliffe index (NS), the best method in both basins was SCS-CN-AF (Rio Chapingo: $\mathrm{AE}=0.002, \mathrm{RE}=0.01, \mathrm{RMSE}=0.14$ and $\mathrm{NS}=0.23$; El Malacate: $\mathrm{AE}=-0.004, \mathrm{RE}=-0.004$, $\mathrm{RMSE}=0.50$ and $\mathrm{NS}=0.36$ ), followed by the NOM method (Rio Chapingo: $\mathrm{AE}=0.56, \mathrm{RE}=4.11, \mathrm{RMSE}=0.70$ and $\mathrm{NS}=-17.94$; El Malacate: $\mathrm{AE}=-0.06, \mathrm{RE}=-0.07$, $\mathrm{RMSE}=0.51$ and $\mathrm{NS}=0.33$ ) and finally by the $\mathrm{SCS}-\mathrm{CN}$ method (Rio Chapingo: $\mathrm{AE}=0.37, \mathrm{RE}=2.73$, $\mathrm{RMSE}=1.18$ and $\mathrm{NS}=-53.15$; El Malacate: $\mathrm{AE}=-0.41$, $\mathrm{RE}=-0.48$, RMSE $=0.99$ and $\mathrm{NS}=-1.55$ ). The results suggest establishing experimental basins in the hydrological regions of Mexico to obtain asymptotic functions in order to estimate the $\mathrm{CN}$ values or adjust the NOM surface runoff factors.
\end{abstract}

Keywords: direct runoff, curve number method, rainfall-runoff modeling, asymptotic function, watershed.

\section{INTRODUCTION}

Knowledge of surface runoff in a basin is transcendent to properly manage the water resource. An accurate estimate of its value can also result in an accurate estimate of the water balance, thereby allowing a balanced allocation of water between the amount available and demanded by users, avoiding for example the conflict over the resource between different sectors and the aquifer depletetion.

Its knowledge is important to design storage and protection works for the towns, and to implement management practices to minimize soil erosion and increase the infiltration of water into the soil. A very useful method to estimate surface runoff is by applying a runoff

*ORCID: http://orcid.org/0000-0001-6045-1661 
coefficient to the rainfall depth. The experimental determination of this surface runoff coefficient in the microbasins of Mexico is very difficult obtain because there is a little information on precipitation and surface runoff. Continuous measurement of surface flow implies a high cost caused by the acquisition, instalation, operation and maintenance of the infrastructure and measuring devices. In most basins is difficult to implement the measurement because of its remoteness, topographical conditions, insecurity or vandalism. For this reason, it is essential to review the accuracy of the methodologies applied to estimate surface runoff on ungauged basins and adapt them to the mexican basins conditions to improve the estimation of the results.

The method proposed by the Mexican Official Standard NOM-011-CNA-2015 (NOM) to estimate the surface runoff coefficient in Mexico is a function of a parameter $\mathrm{K}$ that depends on the use and type of soil [1]. Curve Number method (CN) proposed by the Natural Resources Conservation Service (NRCS), in the decade of the 1950 [2] it is also used to find a relation between surface runoff and precipitation depth for a rain event; this is based on a numerical curve value that depends on the type and use of soil, soil hydrological condition, vegetation, management practices and the humidity conditions that precede the event in study [3]. The K and Curve Number values can be consulted in tables, but they do not guarantee the representation of Mexican basins characteristics because most are taken from information generated in other countries, particularly from EE. UU., and therefore, strong estimation errors of the runoff coefficient can be generated.

Considering the antecedent, in this work the objective is to evaluate the NOM and CN methodologies for surface runoff depth in two small basins of Mexico, with information of rain-runoff events of two years. $\mathrm{CN}$ method was used in two ways depending on the methodology used to assign the value of the curve number; in one way the values were assigned from tables and in the other one they were adjusted with the functions proposed by Hawkins in 1993 [4] and Kowalik and Walega in 2015 [5]. This is intended to know the most appropriate methodology in the ungauged basins of Mexico, with similar conditions to those studied, and propose this study as a reference to policy makers on water management.

\section{MATERIALS AND METHODS}

This work was done in the microbasins Rio Chapingo and El Malacate located in Mexico and Michoacan states, respectively, with information taken from runoff generated en 2014 and 2016 in the first microbasin and in 2013 and 2014 in the second one. The microbasin Rio Chapingo has a surface of 1923.4 ha and El Malacate has 149.2 ha.

\subsection{Considered rainfall-runoff events}

In the microbasin Rio Chapingo, information of 20 rain events that produced runoff was used, from one to five occurred in 2014 and the rest in 2016. In the microbasin El Malacate, 14 runoff events were used, from one to five corresponded to 2013 and the rest to 2014 (Table 1). The precipitation information was taken from a site near the microbasins exit.

To compare the annual results of the observed runoff with those estimated, the $2.7 \mathrm{~mm}$ and $1.86 \mathrm{~mm}$ measured in microbasin Rio Chapingo in 2014 and 2016, respectively, were considered. These values were obtained by dividing the runoff volume between the microbasin area. The runoff volume was obtained from the total of the direct runoff hydrographs, and it was registered at the exit of the microbasins with an automated measurement system. 
Table 1: Characteristics of rainfall-runoff events analyzed.

\begin{tabular}{|c|c|c|c|c|c|c|}
\hline \multirow{2}{*}{ Event } & \multicolumn{3}{|c|}{ Microbasin Rio Chapingo } & \multicolumn{3}{c|}{ Microbasin El Malacate } \\
\cline { 2 - 7 } & $\begin{array}{c}\mathrm{P}^{1} \\
(\mathrm{~mm})\end{array}$ & $\begin{array}{c}\mathrm{Q}^{2} \\
(\mathrm{~mm})\end{array}$ & $\begin{array}{c}\text { Antecedent rainfall } \\
\text { depth }^{3}(\mathrm{~mm})\end{array}$ & $\begin{array}{c}\mathrm{P} \\
(\mathrm{mm})\end{array}$ & $\begin{array}{c}\mathrm{Q} \\
(\mathrm{mm})\end{array}$ & $\begin{array}{c}\text { Antecedent rainfall } \\
\text { depth }(\mathrm{mm})\end{array}$ \\
\hline 1 & 16.00 & 0.168 & 0.00 & 12.60 & 0.490 & 0.00 \\
\hline 2 & 20.50 & 0.662 & 13.33 & 28.20 & 0.631 & 18.80 \\
\hline 3 & 9.50 & 0.088 & 12.00 & 26.80 & 1.370 & 12.80 \\
\hline 4 & 4.70 & 0.057 & 3.06 & 35.80 & 0.873 & 16.00 \\
\hline 5 & 2.90 & 0.015 & 1.89 & 10.60 & 0.858 & 14.60 \\
\hline 6 & 19.90 & 0.291 & 1.00 & 10.80 & 0.360 & 0.00 \\
\hline 7 & 28.70 & 0.449 & 14.00 & 4.00 & 0.181 & 7.80 \\
\hline 8 & 12.00 & 0.090 & 15.00 & 15.20 & 0.270 & 3.00 \\
\hline 9 & 10.40 & 0.046 & 6.76 & 17.60 & 1.225 & 9.00 \\
\hline 10 & 9.60 & 0.008 & 6.24 & 15.40 & 0.539 & 11.00 \\
\hline 11 & 5.60 & 0.034 & 3.64 & 14.60 & 0.505 & 7.00 \\
\hline 12 & 6.20 & 0.114 & 4.03 & 28.60 & 2.404 & 14.00 \\
\hline 13 & 20.10 & 0.075 & 4.00 & 11.60 & 0.459 & 5.00 \\
\hline 14 & 1.10 & 0.068 & 13.00 & 22.20 & 1.850 & 11.00 \\
\hline 15 & 34.60 & 0.259 & 1.00 & & & \\
\hline 16 & 5.40 & 0.038 & 15.00 & & & \\
\hline 17 & 6.40 & 0.076 & 4.16 & & & \\
\hline 18 & 8.70 & 0.063 & 5.66 & & & \\
\hline 19 & 7.20 & 0.038 & 4.68 & & & \\
\hline 20 & 22.80 & 0.073 & 14.82 & & & \\
\hline
\end{tabular}

${ }^{1}$ Rainfall depth; ${ }^{2}$ Surface runoff depth; ${ }^{3}$ Accumulated rainfall depth of 5 days before the event.

\subsection{Runoff depth with Mexican Official Standard method}

The method proposed by the Mexican Official Standard NOM-011-CNA-2015 (NOM) [1], is used to estimate the mean annual runoff depth using eqn (1):

$$
Q=C_{e} P \text {, }
$$

where $\mathrm{C}_{\mathrm{e}}$ is the mean annual runoff coefficient, $\mathrm{Q}$ is the runoff depth [L], and $\mathrm{P}$ is the mean annual precipitation depth [L]. Surface runoff coefficient is a function of K parameter that depends on the use and type of soil (permeability) and the mean annual precipitation. A weighted $\mathrm{K}$ value was used for each study microbasin. This coefficient was calculated with the eqns (2) or (3), according to the weighted $\mathrm{K}$ value

$$
\begin{gathered}
C_{e}=\frac{\mathrm{K}(\mathrm{P}-250)}{2000} \text { for } K \leq 0.15, \\
C_{e}=\frac{\mathrm{K}(\mathrm{P}-250)}{2000}+\frac{(\mathrm{K}-0.15)}{1.5} \text { for } K>0.15
\end{gathered}
$$

Eqns (2) and (3) are valid for annual precipitations between 350 and $2150 \mathrm{~mm}$.

\subsection{Runoff depth with Curve Number method}

Curve Number method (CN) proposed by the Natural Resources Conservation Service was used [1], [6]. Surface runoff depth was calculated with eqns (4), (5) and (6): 


$$
\begin{gathered}
\mathrm{Q}=\frac{\left(\mathrm{P}-\mathrm{I}_{\mathrm{a}}\right)^{2}}{\left(\mathrm{P}-\mathrm{I}_{\mathrm{a}}\right)+\mathrm{S}} \text { valid for } I_{a} \geq P, \text { otherwise } Q=0, \\
\mathrm{I}_{\mathrm{a}}=\lambda \mathrm{S}, \\
\mathrm{S}=\frac{25400}{\mathrm{CN}}-254,
\end{gathered}
$$

where $\mathrm{Q}$ is the generated runoff depth $(\mathrm{mm})$ by the precipitated depth $\mathrm{P}(\mathrm{mm})$ by rain event, $\mathrm{I}_{\mathrm{a}}$ is the initial abstraction $(\mathrm{mm}), \mathrm{S}$ is the maximum soil moisture retention potential $(\mathrm{mm}), \lambda$ is the initial abstraction radius, assumed as 0.2 for this study (dimensionless) as indicated by National Resources Conservation Service [6] and Woodward et al. [7], and CN is the numerical curve value obtained from tables $\left(\mathrm{CN}_{\mathrm{tab}}\right)$ [6], corrected by the antecedent rain condition, being able to take the value of $\mathrm{CN}_{\mathrm{I}}, \mathrm{CN}_{\mathrm{II}}$ or $\mathrm{CN}_{\text {III }}$ as explained below.

Antecedent rain condition was defined with the accumulated precipitated depth of 5 days before the runoff. A dry condition $\left(\mathrm{CN}_{\mathrm{I}}\right)$ was considered if the antecedent accumulated depth was less than $12.7 \mathrm{~mm}$, moderate condition $\left(\mathrm{CN}_{\mathrm{II}}\right)$ if it was between 12.7 and $38.1 \mathrm{~mm}$, and wet condition $\left(\mathrm{CN}_{\text {III }}\right)$ if it was higher than $38.1 \mathrm{~mm}$. Correction for antecedent precipitation conditions was made with eqns (7), (8) and (9) [8]

$$
\begin{gathered}
\mathrm{CN}_{\mathrm{I}}=\frac{\left[4.2 \mathrm{CN}_{\mathrm{tab}}\right]}{10-0.058 \mathrm{CN}_{\mathrm{tab}}}, \\
C N_{I I}=C N_{t a b}, \\
\mathrm{CN}_{\mathrm{III}}=\frac{\left[23 \mathrm{CN}_{\mathrm{tab}}\right]}{10+0.13 \mathrm{CN}_{\mathrm{tab}}} .
\end{gathered}
$$

\subsection{Runoff depth with asymptotic functions (SCS-CN-AF)}

This methodology consisted of applying NC method, but using curve number values adjusted with the asymptotic functions (AF) proposed by Hawkins [4] in 1993 and Kowalik and Walega [5] in 2015. First, curve numbers observed by rain event $\left(\mathrm{CN}_{\mathrm{obs}}\right)$ were calculated, corresponding to the observed precipitated $(\mathrm{P})$ and runoff depths $(\mathrm{Q})$ of the event, ordered as suggested by Hawkins [9] in 2002, applying eqns (10) and (11) [10]

$$
\begin{gathered}
\mathrm{CN}_{o b s}=\frac{25400}{(\mathrm{~S}+254)}, \\
\mathrm{S}=\frac{\mathrm{P}}{\lambda}+\frac{\mathrm{Q}(1-\lambda)}{2 \lambda^{2}}-\frac{1}{2 \lambda^{2}}\left[\mathrm{Q}^{2}(1-\lambda)^{2}+4 \lambda \mathrm{PQ}\right]^{\frac{1}{2}} .
\end{gathered}
$$

Then, the observed curve number values were analyzed together with the observed precipitated depths (P-CNobs) with the TABLE CURVE 2D software [11], to obtain the adjustment parameters of the Hawkins standard function (eqn (12)) and Kowalik and Walega function (eqn (13)):

$$
\begin{gathered}
\mathrm{CN}(\mathrm{P})_{H}=\mathrm{CN}_{\infty}+\left(100-\mathrm{CN}_{\infty}\right) \times e^{\left(-\mathrm{k}_{1} \mathrm{P}\right)} \\
\mathrm{CN}(\mathrm{P})_{K-W}=\mathrm{CN}_{\mathrm{L}}+\left[\mathrm{b}^{1-\mathrm{d}}+\mathrm{c} \times \mathrm{P}(\mathrm{d}-1)\right]^{\frac{1}{1-\mathrm{d}}},
\end{gathered}
$$

where $\mathrm{CN}(\mathrm{P})_{\mathrm{H}}$ is the curve number value of the Hawkins function, $\mathrm{CN}(\mathrm{P})_{\mathrm{K}-\mathrm{W}}$ is the curve number value of the Kowalik and Walega function, $\mathrm{CN}_{\infty}$ is the value that the curve number acquires when the precipitated depth tends to infinity, $\mathrm{CN}_{\mathrm{L}}$ is the curve number value when the precipitated depth acquires a large value, $\mathrm{k}_{1}, \mathrm{c}, \mathrm{b}$ and $\mathrm{d}$ are adjustment parameters, and $\mathrm{P}$ is the precipitation of the event $(\mathrm{mm})$. 


\subsection{Characteristics of the study microbasins}

Microbasin Rio Chapingo presented a mean annual precipitation of $598.6 \mathrm{~mm}$, in the period 1981 to 2010, according to the records of Chapingo weather station located in Texcoco. In the years 2014 and 2016, 932.4 and $619.3 \mathrm{~mm}$ were registered, respectively. It has an average height of $2520 \mathrm{~m}$, average slopes of the basin and main channel of 18.5 and $6.7 \%$, respectively, and a length of currents of $38.33 \mathrm{~km}$. The microbasin is very long since its shape index is 0.07 .

Microbasin El Malacate registered a mean annual precipitation of $920.3 \mathrm{~mm}$ between 1969 and 2007 [12]; in 2013 and 2014, 769.6 and $841.0 \mathrm{~mm}$ were registered, respectively, with a HOBO RG3-M ® pluviograph. It has an average height of $2351.5 \mathrm{~m}$, average slope of $28.8 \%$; main channel average slope of $18.6 \%$, shape index of 0.29 and $4.29 \mathrm{~km}$ of surface currents.

According to the hydraulic conductivity to saturation of the soils, associated with the texture [13] obtained from 18 sites sampled in the microbasin Rio Chapingo and from 7 sites in the microbasin El Malacate, types of soil were defined: A (greater than $8 \mathrm{~mm} \mathrm{~h}^{-1}$ ), $\mathrm{B}\left(4\right.$ to $\left.8 \mathrm{~mm} \mathrm{~h}^{-1}\right)$ and $\mathrm{C}\left(1\right.$ to $\left.4 \mathrm{~mm} \mathrm{~h}^{-1}\right)$.

The hydrological condition of the soil was defined according to the vegetation cover: good for greater than $75 \%$, regular for 50 to $75 \%$ coverage and bad for a cover lower than $50 \%$. With the uses, hydrological conditions and soil type, the curve number values and parameter $\mathrm{K}$ of NC and NOM methods were defined (Tables 2 and 3). For calculations, values weighted by the area of the curve number and $\mathrm{K}$ were used, assigning a proportional value to the area covered by each land use.

Table 2: Characteristics and land uses of the microbasin Rio Chapingo.

\begin{tabular}{|l|c|c|c|c|c|c|}
\hline Land use & $\begin{array}{c}\text { Area } \\
\text { (ha) }\end{array}$ & $\begin{array}{c}\text { Surface } \\
(\%)\end{array}$ & $\begin{array}{c}\text { Hydrological } \\
\text { condition of } \\
\text { the soil }\end{array}$ & Soil type & $\mathrm{CN}_{\text {tab }}$ & $\mathrm{K}$ \\
\hline Irrigation agriculture & 95.75 & 4.98 & Bad & $\mathrm{C}$ & 84 & 0.24 \\
\hline Rainfed agriculture & 719.77 & 37.42 & Bad & $\mathrm{C}$ & 88 & 0.24 \\
\hline Oak forest & 214.19 & 11.14 & Regular & $\mathrm{A}$ & 73 & 0.07 \\
\hline Fir forest & 179.88 & 9.35 & Regular & $\mathrm{A}$ & 73 & 0.07 \\
\hline Pine forest & 64.75 & 3.37 & Regular & $\mathrm{A}$ & 73 & 0.07 \\
\hline Pine-oak forest & 204.75 & 10.65 & Regular & A & 73 & 0.12 \\
\hline Water bodies & 2.94 & 0.15 & Bad & C & 100 & 0.30 \\
\hline Bare soil & 42.47 & 2.21 & Bad & C & 91 & 0.27 \\
\hline Urban zone & 398.92 & 20.74 & Bad & C & 91 & 0.26 \\
\hline Weighted value & & & & & 83.3 & 0.19 \\
\hline
\end{tabular}


Table 3: Characteristics and land uses of the microbasin El Malacate.

\begin{tabular}{|l|c|c|c|c|c|c|}
\hline Land use & $\begin{array}{c}\text { Area } \\
\text { (ha) }\end{array}$ & $\begin{array}{c}\text { Surface } \\
(\%)\end{array}$ & $\begin{array}{c}\text { Hydrological } \\
\text { condition of } \\
\text { the soil }\end{array}$ & Soil type & $\mathrm{CN}_{\text {tab }}$ & $\mathrm{K}$ \\
\hline Rainfed agriculture & 1.77 & $1.19 \%$ & $\mathrm{Bad}$ & $\mathrm{C}$ & 88 & 0.30 \\
\hline $\begin{array}{l}\text { Areas without } \\
\text { vegetation }\end{array}$ & 7.37 & $4.94 \%$ & $\mathrm{Bad}$ & $\mathrm{C}$ & 91 & 0.30 \\
\hline $\begin{array}{l}\text { Eroded forest } \\
\text { grassland }\end{array}$ & 2.74 & $1.84 \%$ & $\mathrm{Bad}$ & $\mathrm{B}$ & 86 & 0.30 \\
\hline Forest & 91.31 & $61.18 \%$ & Good & $\mathrm{A}$ & 70 & 0.24 \\
\hline Forest-grassland & 19.39 & $12.99 \%$ & Regular & $\mathrm{A}$ & 77 & 0.28 \\
\hline Grassland-forest & 24.86 & $16.66 \%$ & Regular & $\mathrm{B}$ & 79 & 0.30 \\
\hline $\begin{array}{l}\text { Reforestation of } \\
\text { eroded areas }\end{array}$ & 1.80 & $1.20 \%$ & Regular & $\mathrm{C}$ & 91 & 0.30 \\
\hline Weighted value & & & & 74.2 & 0.11 \\
\hline
\end{tabular}

2.6 Evaluation of the methods for estimating runoff

The goodness of precision of the models to estimate the considered surface runoff was done with the mean error (AE), relative error (RE) the root mean square error (RMSE) and the Nash-Sutcliffe coefficient (NS), with eqns (14) to (17)

$$
\begin{gathered}
A E=\frac{\sum_{i=1}^{n}\left(Q_{\text {sim }, i}-Q_{o b s, i}\right)}{n}, \\
R E=\frac{\sum_{i=1}^{n} Q_{s i m, i}-\sum_{i=1}^{n} Q_{o b s, i}}{\sum_{i=1}^{n} Q_{o b s, i}}, \\
R M S E=\sqrt{\frac{\sum_{i=1}^{n}\left(Q_{s i m, i}-Q_{o b s, i}\right)^{2}}{n}}, \\
N S=1-\frac{\sum_{i=1}^{n}\left(Q_{o b s, i} Q_{s i m, i}\right)^{2}}{\sum_{i=1}^{n}\left(Q_{o b s, i}-\overline{Q_{o b s}}\right)^{2}},
\end{gathered}
$$

where $\mathrm{Q}_{\text {obs, }, \mathrm{i}}$ is the $\mathrm{i}$-th observed value, $\mathrm{Q}_{\text {sim, } \mathrm{i}}$ is the $\mathrm{i}$-th simulated value and $\overline{Q_{\text {obs }}}$ is the average value of the $n$ observed values.

\section{RESULTS AND DISCUSSION}

\subsection{Asymptotic functions to estimate the value of the curve number}

The functions of Hawkins and Kowalik and Walega resulted with an excellent fit in the two microbasins, slightly better in the microbasin Rio Chapingo. In the two microbasins, the two models resulted with the same value of $\mathrm{R}^{2}$; of 0.997 in the microbasin Rio Chapingo and 0.993 in El Malacate (Table 4). 
Table 4: Asymptotic functions of Hawkins (1993) [4] and Kowalik and Walega (2015) [5].

\begin{tabular}{|c|c|c|}
\hline Model & Microbasin Río Chapingo & Microbasin El Malacate \\
\hline \multirow{3}{*}{$\mathrm{CN}(\mathrm{P})_{\mathrm{H}}$} & $\mathrm{CN}_{\infty}=51.82 ; \mathrm{k}_{1}=-0.034$ & $\mathrm{CN}_{\infty}=62.72 ; \mathrm{k}_{1}=-0.038$ \\
\cline { 2 - 3 } & $=51.82+(48.19) \times \mathrm{e}^{(-0.034 \mathrm{P})}$ & $=62.72+(37.28) \times \mathrm{e}^{(-0.038 \mathrm{P})}$ \\
\cline { 2 - 3 } & $\mathrm{R}^{2}=0.997$ & $\mathrm{R}^{2}=0.993$ \\
\hline & $\mathrm{CN}_{\mathrm{L}}=51.40 ; \mathrm{b}=48.78 ; \mathrm{c}=0.033 ; \mathrm{d}$ & $\mathrm{CN}_{\mathrm{L}}=54.48 ; \mathrm{b}=46.54 ; \mathrm{c}=0.0065 ; \mathrm{d}$ \\
& $=1.0073$ & $=1.42$ \\
\cline { 2 - 3 } $\mathrm{CN}(\mathrm{P})_{\mathrm{K}-\mathrm{W}}$ & $=51.40$ & +0.199 \\
& $+[0.972$ & $\times P(0.42)]^{-2.364}$ \\
\cline { 2 - 3 } & $+0.033 \times P(0.0073)]^{-136.986}$ & $\mathrm{R}^{2}=0.993$ \\
\hline
\end{tabular}

In both basins, it is observed that as the precipitated depth increases, the curve number decreases with an asymptotic tendency for large precipitations as observed [5] (Fig. 1). In the microbasin Rio Chapingo the $\mathrm{CN}_{\infty}$ and $\mathrm{CN}_{\mathrm{L}}$ values were very similar (51.82 and 51.40) but lower than the value of the dry antecedent condition $\left(\mathrm{CN}_{\mathrm{I}}=67.74\right)$, a condition presented in 14 of the 20 analyzed events. In the microbasin El Malacate, $\mathrm{CN}_{\infty}$ value (62.72) was higher than the most frequent antecedent condition $\left(\mathrm{CN}_{\mathrm{I}}=54.72\right)$, whereas $\mathrm{CN}_{\mathrm{L}}$ was very similar (54.48) to the value of that condition.

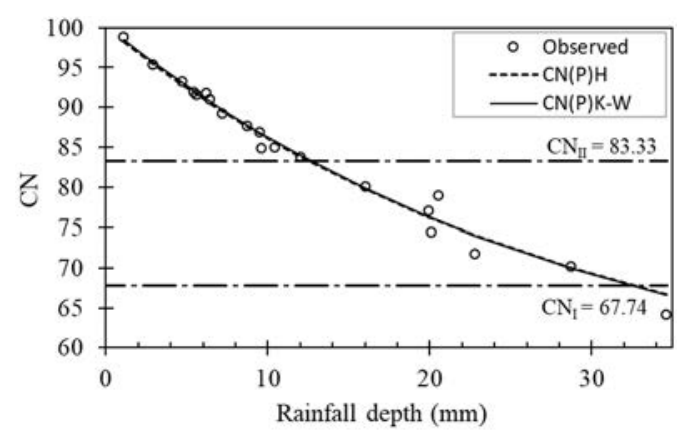

(a)

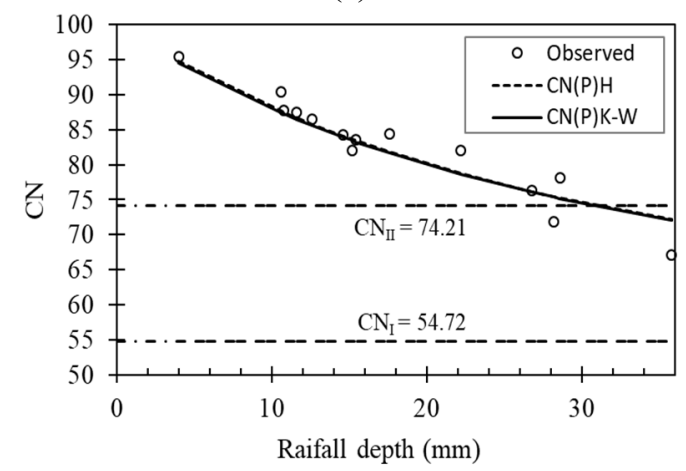

(b)

Figure 1: Pairs of observed and estimated $\mathrm{CN}$ values and rainfall depth. (a) Microbasin Rio Chapingo; (b) Microbasin El Malacate. 


\subsection{Annual runoff with NOM method}

Annual runoff calculated with NOM method overestimated those observed in the two years of study of the two microbasins (Fig. 2). In the microbasin Rio Chapingo the differences were 3059.6 and $1951.6 \%$ in 2014 and 2016, respectively. the differences were much smaller in microbasin El Malacate, with values of 258.7 and 32.1\% in 2013 and 2014, respectively.

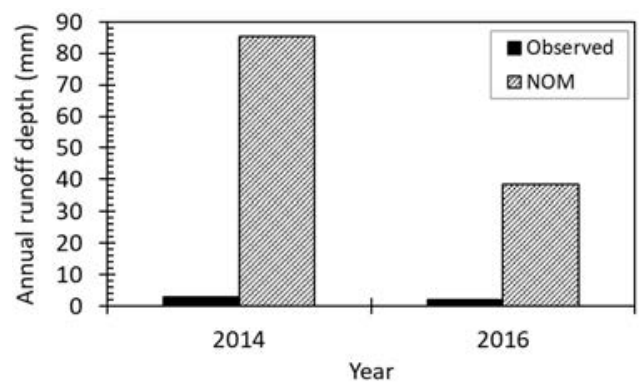

(a)

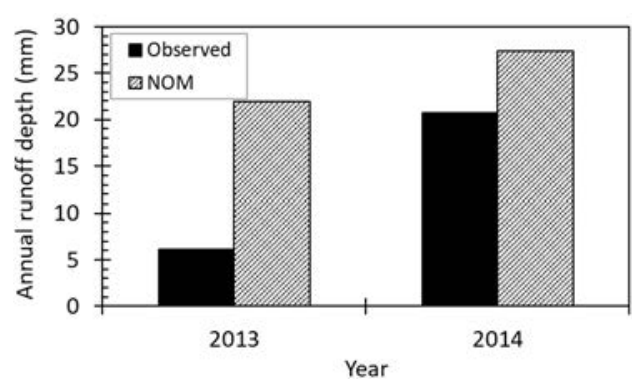

(b)

Figure 2: Annual runoff depths observed and estimated with the NOM method. (a) Microbasin Rio Chapingo; (b) Microbasin El Malacate.

\subsection{Evaluation of the methods}

In the two studied microbasins, $\mathrm{CN}$ method was the least accurate in the estimation of runoff depths. In both microbasins, the methods based on the functions of Hawkins and Kowalik and Walega were the best with very similar results, slightly better the second of them. It is important to note that the estimates per rain event made with the NOM method in the Malacate microbasin results very close to those obtained with the Hawkins and Kowalik and Walega functions, although it is recommended for annual estimates (Tables 5 and 6). In the microbasin Rio Chapingo, $\mathrm{CN}$ method produced runoff events in only five of the rain events with a total depth of $10.11 \mathrm{~mm}$, while in the 20 events studied $2.71 \mathrm{~mm}$ were observed. This method drastically overestimated the runoff depth observed in the events that resulted in runoff. NOM, Hawkins and Kowalik and Walega methods showed runoff in the 20 studied events with values of 13.87, 2.57 and $2.75 \mathrm{~mm}$, respectively (Fig. 3).

Table 5: Statistics of the quality of adjustment of the models to estimate the runoff depths by event in the microbasin Rio Chapingo.

\begin{tabular}{|l|c|c|c|c|}
\hline \multicolumn{1}{|c|}{ Model } & AE (mm) & RE & RMSE (mm) & NS \\
\hline CN & 0.37 & 2.73 & 1.18 & -53.15 \\
\hline NOM & 0.56 & 4.11 & 0.70 & -17.94 \\
\hline Hawkins (1993) & -0.007 & -0.05 & 0.14 & 0.22 \\
\hline Kowalik and Walega (2015) & 0.002 & 0.01 & 0.14 & 0.23 \\
\hline
\end{tabular}


Table 6: Statistics of the quality of adjustment of the models to estimate the runoff depths by event in the microbasin El Malacate.

\begin{tabular}{|l|c|c|c|c|}
\hline \multicolumn{1}{|c|}{ Model } & AE (mm) & RE & RMSE (mm) & NS \\
\hline CN & -0.41 & -0.48 & 0.99 & -1.55 \\
\hline NOM & -0.06 & -0.07 & 0.51 & 0.33 \\
\hline Hawkins (1993) & -0.08 & -0.09 & 0.50 & 0.34 \\
\hline Kowalik and Walega (2015) & -0.004 & -0.004 & 0.50 & 0.36 \\
\hline
\end{tabular}

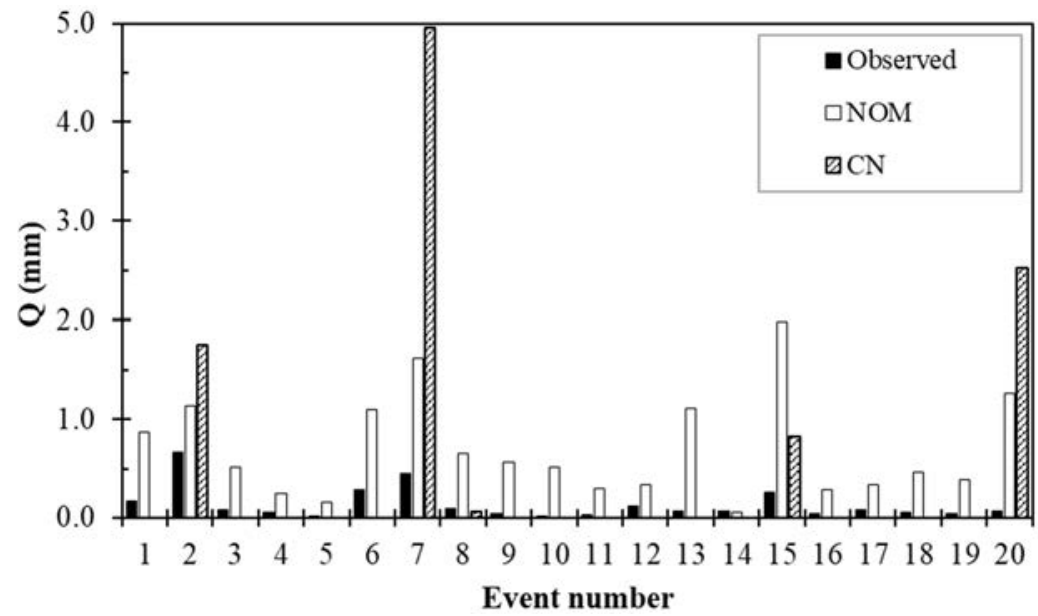

(a)

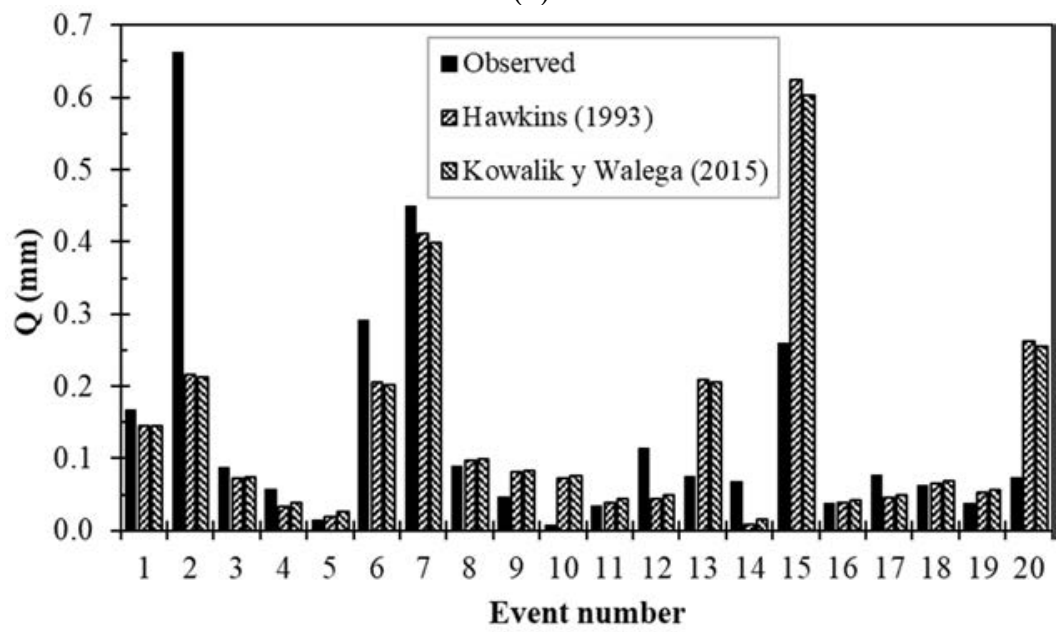

(b)

Figure 3: Runoff depths observed and estimated in the microbasin Rio Chapingo. (a) NC and NOM methods; (b) Methods based on the functions of Hawkins (1993) and Kowalik and Walega (2015). 
It is observed that the Hawkins and Kowalik and Walega methods compensated for the errors of the events since the sum of the estimated runoff depths from the total of events contemplated was very close to that observed with errors of -5.2 and $1.5 \%$, respectively.

In the microbasin $\mathrm{El}$ Malacate, $\mathrm{CN}$ method produced runoff events in only four of the rain events with a total depth of $6.29 \mathrm{~mm}$, while in the 14 studied events, $12.02 \mathrm{~mm}$ were observed. NOM, Hawkins and Kowalik and Walega methods showed runoff in the 14 studied events with values of 11.20, 10.94 and $11.97 \mathrm{~mm}$, respectively (Fig. 4). NOM, Hawkins and Kowalik and Walega methods compensated for the errors of the events since the sum of the runoff depths estimated from the total of events contemplated resulted in differences of -6.8 , -9.0 and $-0.4 \%$, with respect to the observed.

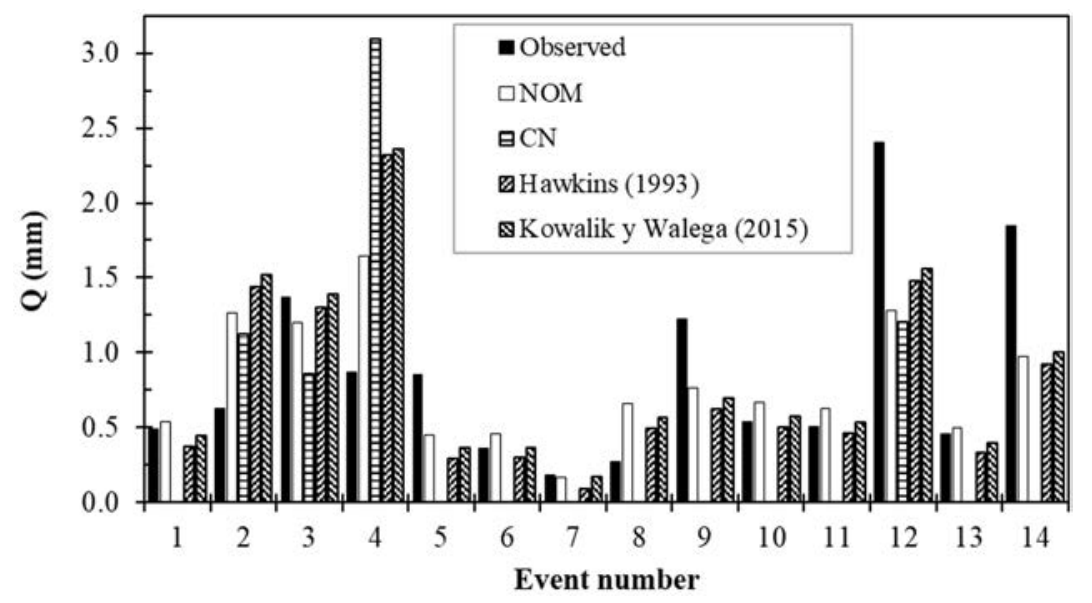

Figure 4: Runoff depths observed and estimated with NOM, CN methods and with the methods based on the functions of Hawkins (1993) [4] and Kowalik and Walega (2015) [5] in the microbasin El Malacate.

The methods were more accurate in the microbasin El Malacate than in the microbasin Rio Chapingo, and it is attributed to the fact that the precipitated depths used were more representative of the entire runoff area in the first case. This is explained by the fact that the precipitated depths registered at the exit of the microbasin Rio Chapingo may not have occurred at other sites of the microbasin due to their elongated shape, while those registered in the microbasin El Malacate probably occurred over their entire surface because it is small and has a pear shape. Consequently, it should be measured in more places inside the microbasin Rio Chapingo, at least in the middle and upper part.

The poor accuracy of $\mathrm{CN}$ method, without the adjustment with the functions of Hawkins and Kowalik and Walega, is due to the fact that the antecedent rain condition does not adequately represent the initial states of soil moisture or water storage by the foliage of the vegetation. In the microbasin Rio Chapingo. 15 of the 20 events corresponded to the dry condition of antecedent rain $\left(\mathrm{CN}_{\mathrm{I}}\right)$ and six to the moderate condition $\left(\mathrm{CN}_{\mathrm{II}}\right)$; however, the observed runoff indicates that the antecedent conditions should be dry for large precipitations, moderate for intermediate ones and wet for small ones (Fig. 5(a)). With this, there would be smaller depths in the events that estimated runoff different to zero and would produce runoff in those where it was null, since four of the five event that produced runoff 
corresponded to the moderate condition and three of them registered high precipitated depths (from 20.5 to $28.7 \mathrm{~mm}$ ).

In the microbasin El Malacate, 9 of the 14 events resulted in the dry antecedent condition and five in the moderate one. In this microbasin the results were better than in the microbasin Rio Chapingo, because four of the moderate antecedent conditions corresponded to four of the five events that estimated a runoff different from zero and corresponded to the four highest precipitations (Fig. 5(b)). However, the precipitation events with precipitated depths less than $20 \mathrm{~mm}$ should correspond to the condition of wet antecedent precipitation, generating non-null runoff.

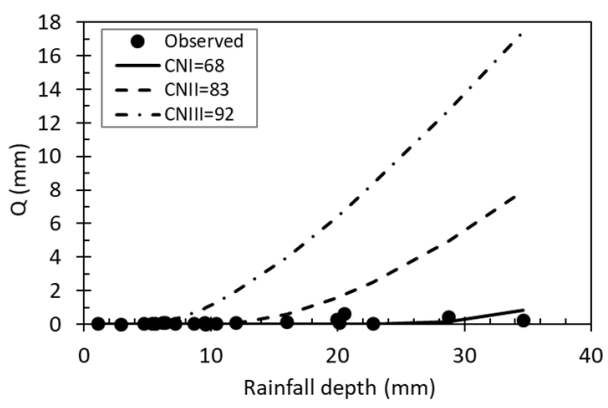

(a)

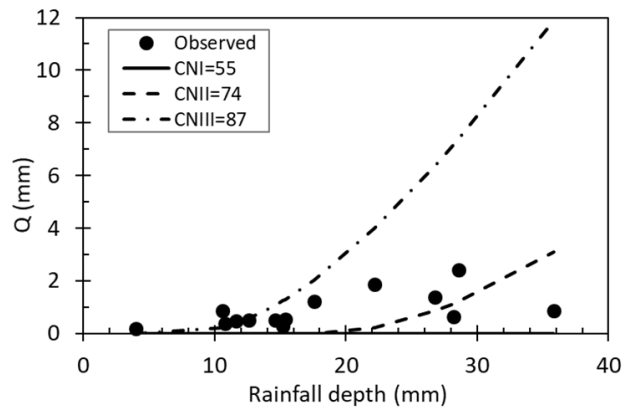

(b)

Figure 5: Runoff depths observed and estimated for dry $\left(\mathrm{CN}_{\mathrm{I}}\right)$, moderate $\left(\mathrm{CN}_{\mathrm{II}}\right)$ and humid ( $\mathrm{CN}_{\text {III }}$ ) condition. (a) Microbasin Rio Chapingo; (b) Microbasin El Malacate.

Although the functions of Hawkins and Kowalik and Walega were excellently fitted, NC method based on them resulted in inaccuracies in some rain-runoff events because the estimated runoff depth is very sensitive to the value of the curve number. Curve number value is difficult to assign because this parameter depends on several aspects and even experienced people may have difficulties, especially in microbasins where information is scarce. The method does not consider the dynamic of water infiltration in the soil or the initial condition of humidity [14], [15] and the retention by foliage of the vegetation is integrated in the abstractions which can vary according to water depth retained by the canopy and shaft at the beginning of the rain and its saturation conditions [16]-[18].

\section{CONCLUSIONS}

CN method based on asymptotic functions of Hawkins (1993) [4] and Kowalik and Walega (2015) [5] (SCS-CN-AF) was the most appropriate to estimate the runoff depths in the two studied microbasins. CN method was the least accurate to estimate the runoff depths in the two studied microbasins. In $70 \%$ of the events the runoff was null, and in the rest the observed values were drastically overestimated.

NOM method was better to estimate the runoff depths per event despite being a suggested method for annual estimates. Estimation methods of analyzed runoff depths were more efficient in the microbasin El Malacate than in the microbasin Rio Chapingo because the precipitated depths were more representative of the entire runoff area.

Policy makers for the water resources management in watersheds must rethink the methodology for carrying out water balances in Mexico, supported by research such as the one presented in this paper. 


\section{REFERENCES}

[1] NORMA, Oficial Mexicana NOM-011-CONAGUA-2015. Conservación del recurso agua- Que establece las especificaciones y el método para determinar la disponibilidad media anual de las aguas nacionales, Diario Oficial, 17 de abril, México, 2002.

[2] Kumar, S.K. \& Singh, V.P. (eds), Soil Conservation Service curve number (SCS-CN) methodology. Water Science and Technology Library, vol. 42, Springer: Dordrecht, pp. 1-83.

[3] López-Cadenas del Ll., F. (ed.), Restauración Hidrológica Forestal de Cuencas y Control de Erosión, Mundi-Prensa: Madrid, p. 945, 1998.

[4] Hawkins, R.H., Asymptotic determination of runoff curve numbers from data. Journal of Irrigation and Drainage Engineering, 119, pp. 334-345, 1993.

[5] Kowalik, T. \& Walega, A., Estimation of CN parameter for small agricultural watersheds using asymptotic functions. Water, 7(3), pp. 939-955, 2015.

[6] National Resources Conservation Service, National engineering handbook. Section 4. www.nrcs.usda.gov/wps/portal/nrcs/detailfull/national/water/manage/hydrology/?cid $=$ STELPRDB1043063.

[7] Woodward, D.E., Hawkins, R.H., Jiang, R., Hjelfment, A.T., Van Mullen, J.A. \& Quan, Q.D., Runoff curve number method: Examination of the initial abstraction ratio. World Water \& Environmental Resources Congress 2003, pp. 1-12, 2003.

[8] Banasik, K., Rutkowska, A. \& Kohnová, S., Retention and curve number variability in a small agricultural catchment: The probabilistic approach. Water, 6, pp. 1118-1133, 2014.

[9] Hawkins, R.H., Woodward, D.E. \& Jiang, R., Investigations of the runoff curve number abstraction ratio. Presented at 2001 USDA-NRCS Hydraulic Engineering Workshop, Tucson, USA.

[10] Schneider, L.E. \& McCuen, R.H., Statistical guidelines for curve number generation. Journal of Irrigation and Drainage Engineering, 131(3), pp. 282-290, 2005.

[11] Table Curve 2D, Systat Software Inc. www.sigmaplot.co.uk/products/tablecurve2d/ tablecurve2d.php. Accessed on: 17 Oct. 2016.

[12] Instituto Mexicano de Tecnología del Agua, Extractor rápido de información climatológica. ERIC III version 2.0, 2009.

[13] Saxton, K. \& Rawls, W., Soil water characteristic estimates by texture and organic matter for hydrologic solutions. Soil Science Society of America Journal, 70, pp. 1569$1578,2006$.

[14] Ficklin, D.L. \& Zhang, M.A., Comparison of the curve number and Green-Ampt models in an agricultural watershed. Transactions of ASABE, 56(1), pp. 61-69, 2013.

[15] Viji, R., Prasanna, P.R. \& Ilangovan, R., Modified SCS-CN and Green-Ampt methods in surface runoff modelling for the Kundahpallam Watershed, Nilgiris, Western Ghats, India. Aquatic Procedia, 4, pp. 677-684, 2015.

[16] Gash, J., Valente, F. \& David, J., Estimates and measurements of evaporation from wet, sparse pine forest in Portugal. Agricultural and Forest Meteorology, 94, pp. 149158, 1999.

[17] Gonzalez, A., Temimi, M. \& Khanbilvardi, R., Adjustment to the curve number (NRCS-CN) to account for the vegetation effect on hydrological processes. Hydrological Sciences Journal, 60(4), pp. 591-605, 2015.

[18] Navar, J., Fitting rainfall interception models to forest ecosystems of Mexico. Journal of Hydrology, 548, pp. 458-470, 2017. 